\title{
The Sustainability of Pre-Service Teachers' Consumer Behaviour for the December Holidays
}

GREgOR TORKAR ${ }^{1}$

$\approx$ The consumer behaviour of Slovenian pre-service teachers for the December holidays and their personal views about sustainable consumption were studied. A total of 130 students of the University of Ljubljana's Faculty of Education took part in the study. The sample consisted of 11 male and 116 female students, while 3 students did not report their gender. The survey was conducted in January 2020. The results show that $95.4 \%$ of the respondents received gifts during their childhood on Saint Nicholas Day, $60.0 \%$ at Christmas and $23.1 \%$ when celebrating the New Year. Almost $13 \%$ of the respondents received gifts three times in December during their childhood. In December 2019, 54.6\% of them gave gifts for Saint Nicholas Day, 65.2\% at Christmas and 10.8\% for the New Year. Christmas has therefore become the most common gift-giving time in December. Students most often give their loved ones sweets, clothes and shoes, and cosmetics. The majority of the respondents spend less than $50 \%$ of their monthly income on gifts for the December holidays. In terms of sustainability, the respondents described their consumer behaviour as follows: (1) giving or receiving things they really need, (2) giving or receiving gifts and wrappings made of recyclable material, (3) giving or receiving nonmaterial gifts, (4) reducing the number of gifts, (5) giving for charity, or (6) not giving gifts at all.

Keywords: consumer behaviour, university students, gifts, education, sustainability 


\section{Potrošniška vedenja bodočih učiteljev v obdobju decembrskih praznikov $\mathrm{z}$ vidikov trajnosti}

GREgOR TORKAR

$\approx$ Preučevali smo potrošniško vedenje bodočih slovenskih učiteljev v obdobju decembrskih praznikov in njihove poglede na trajnostno potrošnjo. V raziskavi je sodelovalo 130 študentov Pedagoške fakultete Univerze v Ljubljani. Vzorec je sestavljalo 11 študentov in 116 študentk, trije študentje pa niso navedli spola. Anketa je bila izvedena januarja 2020. Izsledki raziskave kažejo, da je kar 95,4 \% anketirancev prejelo darila v otroštvu na dan svetega Miklavža, 6o,o \% ob božiču in 23,1 \% ob praznovanju novega leta. Skoraj $13 \%$ vprašanih je decembra v otroštvu prejelo darila trikrat. V decembru 2019 jih je 54,6 \% obdarilo za svetega Miklavža, 65,2 \% za božič in 10,8 \% za novo leto. Božič je torej postal najpogostejši čas obdarovanja v decembru. Študentje najpogosteje podarijo svojim najdražjim sladkarije, oblačila in obutev ter kozmetiko. Večina vprašanih za darila za decembrske praznike nameni manj kot 50 \% svojih mesečnih prihodkov. Z vidikov trajnosti so anketiranci svoja obdarovanja ocenili kot: 1) dajanje stvari, ki jih resnično potrebujejo; 2) dajanje daril in darilnih ovojev iz recikliranega materiala; 3) dajanje nematerialnih daril; 4) zmanjšanje števila daril; 5) dajanje v dobrodelne namene; 6) brez obdarovanja.

Ključne besede: vedenje potrošnikov, študentje, darila, vzgoja in izobraževanje, trajnost 


\section{Introduction}

There is growing recognition of the importance of consumption within debates on sustainable development. Concern about the consumption and overconsumption of natural resources (natural capital) is one of the most important global challenges and is also defined in Sustainable Development Goal 12 , which envisages the achievement of sustainable consumption and production patterns (United Nations, 2015). Promoting education for sustainable consumption is part of education for sustainable development (ESD), which is to be integrated into education programmes is a pertinent strategy (Erjavšek et al., 2021; Thoresen, 2010).

The terminology of sustainable consumption can be traced back to Chapter 4 of Agenda 21, which is the main policy document of the United Nations Conference on Environment and Development held in Rio de Janeiro in 1992. It was later also highlighted at the World Summit on Sustainable Development held in Johannesburg in 2002, when the concept of 'sustainable consumption' became one of the overarching objectives for sustainable development (Jackson, 2014). Definitions of sustainable consumption concentrate on more efficient production of more sustainable products, consumption of more sustainable products, or simply on consuming less (Jackson, 2014; Schrader \& Thøgersen, 2011; Quoquab \& Mohammad, 2020). The vitally important factors of sustainable consumption are consumer behaviour, lifestyle and the culture of consumption, which determine the overall scale of resource consumption (Jackson, 2014).

For several decades, researchers in many scientific fields have been interested in consumer behaviour and its drivers. Consumer behaviour for the December holidays is particularly interesting and worthy of study because it represents religious and cultural rituals that contribute to consumption (e.g., Agarwala et al., 2019; Kimura \& Belk, 2005; Sandikci \& Omeraki, 2007) and affect our common endeavours to achieve sustainable consumption and production (Orellano et al., 2020).

In the present paper, we consider consumer behaviour for the December holidays in the case of Slovenian pre-service teachers attending the Faculty of Education of the University of Ljubljana. Lovšin Kozina and Ponikvar (2015) surveyed the monthly incomes of first-year students at the Faculty of Economics and the Faculty of Education at the University of Ljubljana. Since all of the surveyed students had their own monthly income, this allows us to investigate their consumer behaviour. The paper is organised as follows. In the first section, the relevant literature on consumer behaviour is reviewed, followed 
by an overview of the holiday landscape and consumer education in Slovenia. The second section outlines the research questions. Methodological issues and information about the sample are described in the third section. The fourth section presents the results of the survey with a presentation of quantitative and qualitative data. The last section contains the discussion with conclusions and educational implications.

\section{Consumer behaviour, culture and religion}

Research shows that religious and cultural rituals can contribute to sustainable or unsustainable consumption (Agarwala et al., 2019). Religion can influence consumers and society directly, e.g., fasting and clothing, as well as indirectly, e.g., influences on the values in society (Agarwala et al., 2019). The religious affiliation and religiosity of a person impact different aspects of consumer behaviour, such as materialism, acceptance of new brands, status-seeking, product pricing, etc. (e.g., Delener, 1990; Hirschman, 1981; Essoo \& Dibb, 2004; Islam \& Chandrasekaran, 2020; Sood \& Nasu, 1995; White et al., 2018). For an overview of religiosity and consumer behaviour, see Agarwala et al. (2019).

Marshall (2014) argues that in the past few decades Christmas has become a consumer holiday highly influenced by the mass media and advertising, which are both major influences on the increase of consumerism. It is now believed that it is the norm to spend a lot of money on family and friends at this time of year. In their study of Christmas celebrations in Japan, Kimura and Belk (2005) argue that Christmas, which is traditional in Western societies, is supported by cultural ideologies that can either substitute traditional local holidays or, as Sandikci and Omeraki (2007) argue, revive and modify existing local rituals. They also argue that commercial logic and consumerist ideology, as represented by Christmas, hybridise Western and non-Western traditions and practices, creating new expressions of existing rituals. Trommsdorff (2012) points out that the relation between culture and religiosity is symbiotic. Therefore, it is essential to take into account intra-cultural and cross-cultural differences while analysing universal religious processes (Agarwala et al., 2019) and their impact on consumer behaviour.

\section{Transformations of holidays in the recent history of Slovenia}

Holidays are a tool to draw attention to certain collective themes, ideals and values of the past, present and future (Jezernik, 2013). Over the course of the last century, and especially after the Second World War, the holiday landscape in Slovenia underwent radical changes due to political upheavals and the 
restructuring of society and the economy (Slavec Gradišnik, 2015). Church and state were formally separated and former religious holidays became working days. The Committees of the Communist Party introduced new holidays and celebrations (Slavec Gradišnik, 2013); for example, Christmas trees were renamed "New Year's trees", on New Year's Day gifts were brought by Father Frost, who was imported from the Soviet Union and replaced Saint Nicholas (Slavec Gradišnik, 2015). Until 1991, Slovenia was part of socialist Yugoslavia. Later, it became an independent country and part of the European Union. In the postsocialist decades, there was a mix of new state holidays, reintroduced religious holidays, revived folk or traditional holidays, "imported" holidays, and traces of socialist holidays (Slavec Gradišnik, 2013, 2015). These intersections of holiday landscapes and identities in Slovenia are still present in different families, generations, regions, etc. (Slavec Gradišnik, 2013, 2015) and therefore represent an interesting framework in which to study consumer behaviour.

\section{The school system and consumer education in Slovenia}

In Slovenia, children can be enrolled in preschool education as early as at the age of 11 months and attend it until they start compulsory school. Nineyear compulsory school is divided into three three-year cycles (for students six to fourteen years old). The first six years can be recognised as the primary (ISCED 1) level, while grades 7-9 are internationally recognised as the lower secondary school (ISCED 2). Upon completion of compulsory basic education, students - typically aged 15 - may choose to continue their education at the upper secondary level at a school and a programme of their own choice (ISCED 3 ) (taking from two to five years to complete). Upper secondary education programmes are either general or vocational. The upper secondary educational qualification is awarded only after passing the final examination (matura, leaving examination), which also grants the right to enrol in higher levels of education.

Šmid Božičevič and Kostanjevec (2006) note that there is very little systematic consumer education of children and adolescents in the Slovenian school system. Children form their needs, desires and habits mainly under the influence of peers and role models, which is exploited by advertising. Parents are in an unenviable position because children cannot resist certain desires or are not reasonable. This is one of the reasons why consumer education is necessary for children and adults. Sedmak and Erčulj (2009) state that topics related to consumer education are most comprehensively and concretely covered in the subject Home Economics in the fifth and sixth grades. In the subjects of civic education and ethics, there are slightly fewer consumer topics, but they 
are still comprehensively covered. Moreover, in subjects like biology, geography, history, etc. there are some learning objectives related to consumer behaviour or consumption (Sedmak \& Erčulj, 2009). In upper secondary education programmes, the situation regarding consumer education is worse. In general, formal consumer education (as in Home Economics) does not appear in secondary education programmes (Šmid Božičevič \& Kostanjevec, 2006); only some learning objectives related to consumer behaviour or consumption are addressed in subjects such as psychology, geography, sociology, etc. This is somewhat surprising, as upper secondary school students are quite active consumers; they are also already entering the labour market and consequently have their own money at their disposal (Sedmak \& Erčulj, 2009).

Consumer behaviour is closely related to consumer financial behaviour and financial literacy. The $\operatorname{OECD}(2005$, p. 26) defines financial education as "the process by which financial consumers/investors improve their understanding of financial products and concepts and, through information, instruction and/or objective advice, develop the skills and confidence to become more aware of financial risks and opportunities, to make informed choices, to know where to go for help, and to take other effective actions to improve their financial well-being”. Lovšin Kozina and Ponikvar (2015) found that first-year university students in Slovenia have low financial literacy and are vulnerable when they have to make financial decisions. The authors recommend that they are given the opportunity to choose subjects in which they receive basic knowledge in order to be prudent consumers.

\section{Aim and research questions}

The aim of the present study was to explore pre-service teachers' consumer behaviour in the context of the December holidays in Slovenia, as well as to explore their views on sustainability issues in the context of December gifting by concentrating on themes derived from qualitative data. The research questions are as follows:

1. What are pre-service teachers' childhood experiences with receiving gifts on the December holidays?

2. What are their current practices of consumer behaviour for the December holidays?

3. How much of their monthly income is spent on gifts for the December holidays?

4. How do pre-service teachers perceive the sustainability of their consumer behaviour for the December holidays? 


\section{Method}

Quantitative and qualitative research approaches were integrated on the level of research questions, methods and data analysis.

\section{Questionnaire and procedure}

Students completed an online questionnaire designed for this study. Prior to use, the questionnaire was reviewed by two experts on the topic to verify its validity. In a pilot test, eight students completed the questionnaire and filled out a short report about their understanding of the questions and the operation of the online questionnaire. No major difficulties were reported, so no changes to the wording were made, just some minor formatting changes.

The questionnaire was then sent to the students by email with an introductory letter and a link to the questionnaire. After fourteen days, the students were reminded again to complete the questionnaire. The questionnaire was completed between 7 January and 2 February 2020. In addition to questions about consumer behaviour for the December holidays, the survey gathered data on the respondents' age, year of study and religious affiliation. The participants answered closed and open-ended questions about their experiences in giving and receiving gifts for Saint Nicholas Day, Christmas (Santa Claus or Christkind) and the New Year (Father Frost). They reported the types of gifts they give and the proportion of their monthly income (ranks: 0-5, 6-10, 11-20, $21-30,31-40$, etc.) spent on gifting. There was also an open question asking respondents to explain whether and how sustainability issues affect their December gift giving. Finally, they were asked to share an interesting experience or a story related to gifting in December.

\section{Respondents}

Based on a knowledge of the population and the purpose of the study, a purposive sampling technique was used. In purposive sampling, researchers select the cases to be included based on their assessment of the typicality or presence of the characteristics they are looking for, thus creating a sample that meets their specific requirements. This kind of sampling can be used to access those who have in-depth knowledge on specific topics (Cohen et al., 2017). The questionnaire was sent to pre-service preschool, primary school and twosubject teachers of the University of Ljubljana's Faculty of Education. None of the respondents had taken consumer education courses at the tertiary level of 
education prior to the study. Education staff at preschool and school level have to hold relevant educational qualifications (ISCED 6 for preschool teachers, ISCED 7 for primary school and other teachers) and must pass the state professional examination for education staff (Eurydice, 2019).

A total of 300 students were reached by email, and 130 students took part in the study (43.3\% of all of the invited students). The respondents were in their first or second year of undergraduate studies. The sample comprised 11 male and 116 female students, while 3 students did not report their gender. The gender proportions in the sample are normal for Slovenian schools.

The vast majority of the respondents described themselves as Catholic $(73.2 \%)$, while $20.5 \%$ were atheists or nonreligious (henceforth described as atheists), $4.7 \%$ refused to answer the question regarding their religious affiliation, and $1.6 \%$ were members of other faiths (Jews). More than half of the Slovenian population actively practises religion, mostly Roman Catholicism (57.8\%), Islam (2.4\%), Eastern Orthodoxy (2.3\%) and Lutheranism (0.8\%). Some (2.3\%) are believers who adhere to no religion. The information is unknown for $7.3 \%$ of the population, while $25.9 \%$ of the population are non-religious or refused to answer (Črnič et al., 2013). According to the results of the latest study (Naterer et al., 2019), in the age group between 16 and 27 years old, 52\% declared themselves as Catholics, $10 \%$ as members of other religious groups, and $38 \%$ as non-believers. Among the latter group, 44\% declared that they had never participated in organised religious activities.

\section{Data analysis}

The Statistical Package for the Social Sciences (IBM SPSS Statistics, Version 22) was used for quantitative data analysis. According to the research questions, descriptive procedures (absolute and relative frequency) were applied.

The qualitative data were analysed using structured content analysis. Deductive and inductive methods were combined to develop the coding scheme. Deductive categories were derived directly from the research questions. Inductive categories were added during the coding process using in vivo coding to account for unexpected effects. Two independent coders coded the open-ended questions and then compared the assigned categories. Deviant and ambiguous coding was then discussed. The coding rules allowed for multiple categories to be assigned to a respondent's response. The coded text passages were then paraphrased and summarised for each category and each respondent. To clarify whether the effects were individual phenomena or applied to a larger portion of the group, the number of statements about specific effects in the sample was also recorded. 


\section{Results}

The results are structured according to the main research questions of the study by consolidating the results of qualitative and quantitative data. The results presented in Table 1 show that $95.4 \%$ of the respondents received gifts in childhood on Saint Nicholas Day (Saint Nicholas), 60.0\% at Christmas (Santa Claus, in three cases by Christkind) and 23.1\% when celebrating the New Year (Father Frost). More than half of the students (55.4\%) received gifts on Saint Nicholas and Christmas. Almost 13\% of the respondents received gifts on all three occasions in December and one received no gifts.

\section{Table 1}

Respondents receiving gifts as children on the December holidays

\begin{tabular}{lccc}
\hline & Saint Nicholas & Christmas & New Year \\
\hline Saint Nicholas & $95.4 \%$ & $55.4 \%$ & $21.5 \%$ \\
Christmas & $55.4 \%$ & $60.0 \%$ & $14.6 \%$ \\
New Year & $21.5 \%$ & $14.6 \%$ & $23.1 \%$ \\
\hline
\end{tabular}

The respondents shared some very interesting stories and experiences about gifting in December, which illuminate the results presented in Table 1.

"When I was younger, I got little things for all three good men [Saint Nicholas, Santa Claus, Father Frost]" R4

"[...] when my brother and I were younger, we were gifted by Saint Nicholas and Father Frost." R8

"At my boyfriend's home, they have a custom of gifting one another only for Saint Nicholas, and at my house only for Santa Claus, so I bring him a gift for Christmas and he brings me one for Saint Nicholas, even though we both go to church, etc." R31

Their pattern of giving gifts is different from the pattern they experienced in childhood (Table 2). Most of them (65.2\%) gave gifts in December 2019 at Christmas, while 54.6\% gave gifts on Saint Nicholas Day and $10.8 \%$ at the turn of the year. The majority of the students gave gifts once (61.4\%) and the rest two times. Almost one third of the students (30.9\%) gave gifts on Saint Nicholas Day and Christmas. 


\section{Table 2}

Respondents giving gifts on the December holidays

\begin{tabular}{lccc}
\hline & Saint Nicholas & Christmas & New Year \\
\hline Saint Nicholas & $54.6 \%$ & $30.9 \%$ & $6.3 \%$ \\
Christmas & $30.9 \%$ & $65.2 \%$ & $6.1 \%$ \\
New Year & $6.3 \%$ & $6.1 \%$ & $10.8 \%$ \\
\hline
\end{tabular}

This transition to gifting on Christmas is also captured in the description of an experience by one of the respondents.

"[...] when I was a child, it was not a custom at all in our homes to give presents for Christmas. This has infiltrated to us in the last few years perhaps because of globalisation?" R33

The students were also asked to select three types of gifts they usually give. The most frequently given groups of gifts $(>30 \%)$ are presented in Table 3. The students most often give their loved one's sweets, clothes and shoes, and cosmetics.

\section{Table 3}

Most frequently given groups of gifts (>30\%)

\begin{tabular}{lll}
\hline Saint Nicholas & Christmas & New Year \\
\hline Sweets (80.9\%) & Sweets (69.9\%) & Sweets (78.6\%) \\
Clothes and shoes (60.3\%) & Clothes and shoes (57.5\%) & Cosmetics (50.0\%) \\
Cosmetics (38.2\%) & Cosmetics (50.7\%) & Clothes and shoes (42.9\%) \\
Fruit and nuts (35.3\%) & Home equipment (30.1\%) & \\
\hline
\end{tabular}

Figure 1 shows the proportion of monthly income used on gifts for the December holidays. A proportion of monthly income spent on gifts for Saint Nicholas Day, Christmas and the New Year was calculated. Three quarters $(75.4 \%)$ of the students spent less than $50 \%$ of their monthly income on gifts for the December holidays, with the spending most frequently being within the range $31-40 \%$. 


\section{Figure 1}

Monthly income spent on gifts for the December holidays

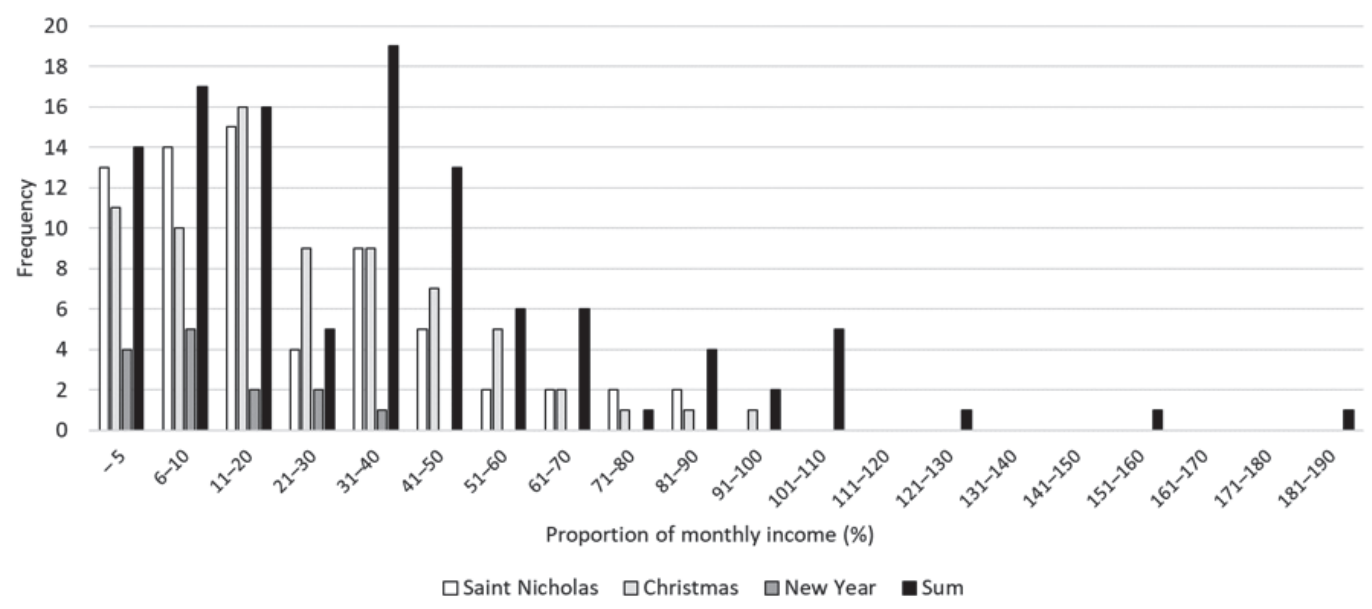

Views on sustainability issues in the context of December gifting were explored with an open-ended question asking the respondents to describe whether and how sustainability issues affect their December gifting. The students' answers were coded into multiple categories and then analysed in the context of sustainable consumption definitions. It was not obligatory to answer the question. A total of 28 (21.5\%) of the students responded. In five responses, the respondents reported not thinking about sustainability issues in consumer behaviour for the December holidays. We assume that among the respondents who did not answer the question, many do not think about sustainability or do not have a suitable understanding of sustainability and therefore did not answer. Different effects were described by the respondents. Several of them (R) stated that they give or receive only things they really need, practical things, such as shoes, socks or underwear.

"[...] I receive from my parents the things I need, for example, winter boots, a jacket, underwear, and this is considered as a gift for Saint Nicholas or Santa Claus." R1

"[...] Mum gives everyone socks and underwear, and we prepare different types of surprises for her, e.g., we bake cookies." R8

"I stick to buying what I think a person really needs and not some pointless things." R25 
One respondent also mentioned the intention of this kind of behaviour.

“[...] to buy what they really need and won't throw away". R17

The next most frequently mentioned category of responses was sustainability of the gifts in terms of the produced materials.

"I try to buy as few plastic things as possible, such as books or wooden toys." R15

"[...] I also always wrap gifts in paper and try to use and buy as few packaged products as possible." R21

Two of the respondents emphasised nonmaterial presents, such as family trips and playing board games during the December holidays.

“[...] we don't gift each other traditionally, we prefer to go on a trip, ski, have lunch together..." R8

"[...] instead of material goods, it means more to me to spend time with my loved ones, to talk, play board games and go on a trip." R23

Two of the respondents mentioned that their families had reduced the number of gifts. They consume less for gifts for the December holidays.

"We buy just one gift for each and then draw who will receive it." R12 "[...] each draws one, who then buys him or her a gift, which we exchange around Christmas." R3

"[...] each buy only one [gift]. A draw determines who gives to whom. The rest are not supposed to know whom you are gifting. We determine the value of gifts in advance $(€ 20-30)$. We think this is better than giving everyone a little something, as this is usually not very useful and everyone is only piled with sweets [...]." R27

Two of the respondents highlighted the category of charity towards others as an aspect of sustainability.

"[...] instead of gifts for loved ones, I bought a picture and donated a voluntary contribution of $€ 30$ for it, which was entirely intended for a shelter for abandoned animals in Ljubljana." R16

"I participated as a 'Santa for a Day' [advertising initiative in the media] 
gifting children from more socially disadvantaged families. I find it a great opportunity to show charity." R27

A single respondent pointed out that in her family they do not give each other gifts for the December holidays anymore.

"When I was younger, I got little things for all three good men [Saint Nicholas, Santa Claus, Father Frost], now that I'm older we don't do that anymore, because we don't agree with the material and usually useless gifts we give just to give someone a gift." R4

\section{Discussion}

Sustainable consumption is an area of global interest, given the Earth's increasing human population and indications of negative impacts on the environment (United Nations, 2015). The main aims of the present research were to explore consumer behaviour in the context of the December holidays.

The presented findings from a sample of Slovenian pre-service teachers reveal that the radical political changes over the course of the last century (Slavec Gradišnik, 2013, 2015) influenced students' experiences with regard to receiving gifts in childhood in the December holidays. They received gifts on Saint Nicholas Day (Saint Nicholas), Christmas Day (Santa Claus or Christkind) and/or New Year's Day (Father Frost), and not infrequently on all three occasions.

One interesting finding is that the pattern of consumer behaviour for the December holidays is changing. The present consumer behaviour (in December 2019) of the respondents no longer reflects the family rituals from their childhood. Whereas, in the past, the main gift-giving holiday was Saint Nicholas Day, today Christmas is given priority. We share the opinion of other authors who have pointed out the growing globalisation and commercialisation of Christmas, which goes beyond religious and cultural traditions (Kimura \& Belk, 2005; Marshall, 2014; Sandikci \& Omeraki 2007). Christmas is becoming a global holiday of high material consumption that can be compared to Valentine's Day or Halloween.

The average percentage of monthly income spent by the surveyed students on gifts for the December holidays $(31-40 \%)$ is not negligible. Therefore, considering the low financial literacy of university students in Slovenia (Lovšin Kozina \& Ponikvar, 2015), it is worth studying their consumer behaviour for the December holidays, as it represents a significant expense for students. 
The second part of the discussion is devoted to the influences of sustainable thinking on consumer behaviour itself. It is noticeable that some of the respondents justify consumer behaviour or gifting by limiting purchases to useful and practical products, and/or products made of natural materials. The practicality and usability of the products is also evident from the groups of gifts they frequently choose to give, such as clothing and cosmetics. The respondents' answers could be classified into three types of more sustainable consumer behaviours (types 1, 2 and 3 are arranged from lower to higher personal sacrifice):

Replacing traditional gifts with more "efficient" gifts (i.e., limiting gifting to useful and practical products, or to gifts made of natural materials).

Alternative consumer behaviours (i.e., giving nonmaterial gifts).

Reducing consumption (i.e., reducing the number of gifts, giving for charity, or not giving gifts at all).

Only one respondent reported not giving gifts at all for the December holidays, which could also be considered a sustainable consumer behaviour. Stern (2000) distinguishes between public and private environmental actions. The three types of behaviour listed above are private environmental actions, whereby individuals consume fewer resources by using technological innovations (e.g., energy efficient appliances) and alternative behaviours (e.g., using public transport) or by reducing consumption of resources (e.g., reduction in purchasing) (Clayton \& Myers, 2015).

\section{Conclusions}

The present study can help teachers consider how to further design consumer education. It is important to start from students' consumption patterns, which are a reflection of the time and place in which they live. However, the question of the quality of consumer education remains open, and studies like this reveal that students are certainly active consumers, influenced by different drivers that contribute to their consumption patterns.

The qualitative part of the research provided a basic insight into the students' mindset, which can be a valuable source of vignettes that students can easily identify with. Vignettes can be useful educational material to learn from and discuss, enabling us to evaluate sustainable consumer behaviours. From the definitions of sustainable consumption highlighted in the introduction, we can conclude that pre-service teachers focus on more sustainable products or simply on consuming less. Due to the fairly low response rate to this particular question, there is still room for future studies to further explore perceptions of sustainable consumption. 


\section{References}

Agarwala, R., Mishra, P., \& Singh, R. (2019). Religiosity and consumer behavior: A summarizing review. Journal of Management, Spirituality \& Religion, 16(1), 32-54.

Clayton, S., \& Myers, G. (2015). Conservation psychology: Understanding and promoting human care for nature. John Wiley \& Sons.

Cohen, L., Manion, L., \& Morrison, K. (2017). Research methods in education. Routledge.

Črnič, A., Komel, M., Smrke, M., Šabec, K., \& Vovk, T. (2013). Religious pluralisation in Slovenia.

Teorija in praksa, 50(1), 205-232.

Delener, N. (1990), The effects of religious factors on perceived risk in durable goods purchase decisions. Journal of Consumer Marketing, 7(3), 27-38.

Erjavšek, M., Lovšin Kozina, F., \& Kostanjevec, S. (2021). In-service home economics teachers' attitudes to the integration of sustainable topics in the home economics subject. Center for Educational Policy Studies Journal, 11(1), 27-47.

Essoo, N., \& Dibb, S. (2004). Religious influences on shopping behaviour: An exploratory study. Journal of Marketing Management, 2o(7-8), 683-712.

Hirschman, E. C. (1981). American Jewish ethnicity: Its relationship to some selected aspects of consumer behavior. Journal of Marketing, 45(3), 102-110.

Islam, T., \& Chandrasekaran, U. (2020). Religiosity and consumer decision making styles of young Indian Muslim consumers. Journal of Global Scholars of Marketing Science, 30(2), 147-169.

Jackson, T. (2014). Sustainable consumption. In G. Atkinson, S. Dietz, E. Neumayer, \& M. Agarwala (Eds.). Handbook of sustainable development (pp. 279-290). Edward Elgar Publishing. https://doi.org/ $10.4337 / 9781782544708.00029$

Jezernik, B. (2013). Politika praznovanja [The politics of celebration.] In B. Jezernik (Ed.), Politika praznovanja: Prazniki in oblikovanje skupnosti na Slovenskem (pp. 7-16). Znanstvena založba Filozofske fakultete.

Kimura, J., \& Belk, R. (2005). Christmas in Japan: Globalization versus localization. Consumption Markets \& Culture, 8(3), 325-338.

Lovšin Kozina, F., \& Ponikvar, N. (2015). Financial literacy of first-year university students: The role of education. International Journal of Management, Knowledge and Learning, 4(2), 241-255.

Marshall, A. (2014). The holidays are coming!: Consumerism and post-Fordist society. Critical Reflections: A Student Journal on Contemporary Sociological Issues, 2, 38-41.

Moschis, G. P., \& Ong, F. S. (2011). Religiosity and consumer behavior of older adults: A study of subcultural influences in Malaysia. Journal of Consumer Behaviour, 10(1), 8-17.

Naterer, A., Lavrič, M., Klanjšek, R., Flere, S., Rutar, T., Lahe, D., Kuhar, M., Hlebec, V., Cupar, T., \&

Kobše, Ž. (2019). Slovenska mladina 2018/2019 [Slovenian youth 2018/2019]. Friedrich-Ebert-Stiftung. OECD. (2005). Improving financial literacy: Analysis of issues and policies. OECD.

Orellano, A., Valor, C., \& Chuvieco, E. (2020). The influence of religion on sustainable consumption: A systematic review and future research agenda. Sustainability, 12(19), 7901. 
Quoquab, F., \& Mohammad, J. (2020). A review of sustainable consumption (2000 to 2020): What we know and what we need to know. Journal of Global Marketing, 33(5), 305-334.

Sandikci, Ö., \& Omeraki, S. (2007). Globalization and rituals: Does Ramadan turn into Christmas? Advances in Consumer Research, 34, 610-615.

Schrader, U., \& Thøgersen, J. (2011). Putting sustainable consumption into practice. Journal of Consumer Policy, 34(1), 3-8.

Sedmak, S., \& Erčulj, J. (2009). Pojem trajnostnega razvoja v učnih načrtih [The concept of sustainable development in curricula]. In S. Sedmak (Ed.), Danes za jutri: Razmišljanja o vzgoji in izobraževanju za trajnostni razvoj (pp. 57-76). Univerza na Primorskem, Fakulteta za management. Sedmak, S. (2009). Trajnostna potrošnja in izobraževanje [Sustainable consumption and education.] In S. Sedmak (Ed.), Danes za jutri: Razmišljanja o vzgoji in izobraževanju za trajnostni razvoj (pp. 113-124). Univerza na Primorskem, Fakulteta za management.

Slavec Gradišnik, I. (2013). Ubrani in razglašeni decembrski čas [Harmonious and dissonant December time.] In I. Slavec Gradišnik (Ed.), Praznična večglasja: Prazniki in oblikovanje skupnosti na Slovenskem (pp. 133-163). Znanstvena založba Filozofske fakultete.

Slavec Gradišnik, I. (2015). A festive bricolage: The holiday calendar in Slovenia over the last century. Folklore: Electronic Journal of Folklore, 60, 29-50.

Sood, J., \& Nasu, Y. (1995). Religiosity and nationality: An exploratory study of their effect on consumer behavior in Japan and the United States. Journal of Business Research, 34(1), 1-9. Stern, P. (2000). Toward a coherent theory of environmentally significant behavior. Journal of Social Issues, $56(3), 407-424$.

Šmid Božičevič, U., \& Kostanjevec, S. (2006). Smernice potrošniškega izobraževanja odraslih v Sloveniji, stanje in priporočila [Guidelines for adult consumer education in Slovenia, current situation and recommendations]. Zveza potrošnikov Slovenije, Strokovno združenje nutricionistov in dietetikov.

Thoresen, V. (2010). Here and now! Education for sustainable consumption: Recommendations and guidelines. United Nations Environmental Programme. https://www.unenvironment.org/resources/ report/here-and-now-education-sustainable-consumption-recommendations-and-guidelines Trommsdorff, G. (2012). Cultural perspectives on values and religion in adolescent development: A conceptual overview and synthesis. In G. Trommsdorff \& X. Chen, (Eds.), Values, religion, and culture in adolescent development (pp. 3-45). Cambridge University Press.

United nations. (2015). Transforming our world: The 2030 agenda for sustainable development. United Nations, Department of Economic and Social Affairs. https://sdgs.un.org/2030agenda White, G. R. T., Samuel, A., Zhou, P., Razak, A. A., \& Thomas, S. (2018). Religious heterogeneity of food consumers: The impact of global markets upon methods of production. Journal of Consumer Behaviour, 17(1), 3-12. 


\section{Biographical note}

Gregor Torkar, $\mathrm{PhD}$, is an associate professor at the Department of Biology, Chemistry, and Home Economics at the Faculty of Education of the University of Ljubljana. His research field is biology and environmental education within the primary, secondary and undergraduate level of education. His current research focus is ecology, evolution, conservational education and education for sustainable development. He is involved in several national and international research projects on science education and nature conservation. 